Mr. Sclater read an extract from a letter addressed to him by Dr. H.Bolau, C.M.Z.S., Director of the Zoological Garden, Hamburg, and dated Hamburg, June 8th. In reply to inquiries Dr. Bolau stated that there were now two examples of Sea-Eagles referred to Haliaëtus pelagicus living in the Hamburg Garden. One of these, received as a present from a ship-captain, Decenber 12th, 1882, had been brought from Amoor-land ; the second, received on February 6th, 
any knowledge of the intermediate forms, would unhesitatingly pronounce them as representing distinct species : they have, in fact, been referred to distinct genera by such experienced workers as Peters and Cope. But if we pursue our investigations over the wide area occupied by this Frog, viz. the whole of the Palæarctic Region, we soon find all the differences by which we were at first struck to blend through such a number of intermediate forms as to leave no other course open but to maintain intact the Linnean species. However, a great difficulty still remains to be dealt with: the principal of the differences ascertained are not merely individual; nor are they entirely dependent on locality or climate, as almost identical specimens are met with at such distant points as North Germany, the Sahara, and Baluchistan. And, what is more striking still, in the case of two forms occurring in the same country, they may be perfectly separable and not interbreed, as has been shown to be the case in Germany. It is therefore not serving the interest of exact taxonomy and zoogeography to be satisfied with the compreherisive notion of Rana esculenta. Attempts should be, and have been, made at a division of the specific type into races or subspecies. With this object in view, I have, for the last few years, been amassing material and information, and have subjected the many hundreds of specimens which have passed through my hands to a most minute examination and comparison.

Although I have, unfortunately, failed in my attempt at drawing very sharp demarcation lines between the various forms, I am still in hopes that others may be more successful; and with the object of furnishing them with a basis for future researches, I venture to publish the following notes, which at the same time show the extent of the material upon which I have worked.

The first attempt at subdividing Rana esculenta into subspecies, published by Camerano in $1881^{1}$, proved on the whole a failure. The two groups into which the species was divided are quite arbitrary ; the author's typical form appears to include part of $\boldsymbol{R}$. ridibunda, and his var. lessonce evidently embraces specimens of the typical form. In various papers ${ }^{2}$ I have endeavoured to throw some light on the matier, and my contributions have been supplemented by Bœttger and Wolterstorff. The latest work on the subject is from the pen of $\mathbf{J}$. de Bedriaga ${ }^{3}$, who admits four forms in Europe and Western Asia, or one more than I am able to recognize, the Spanish-North-African specimens being regarded by him as forming a subspecies distinct from $R$. ridibunda $=$ fortis .

I now propose to divide Rana esculenta into four principal forms, viz. :-

1. Var. RIDIBUNDA.

$=R$. ridibunda, Pall., $R$. cachinnans, Pall., $R$. caucasica, Pall.,

${ }^{1}$ C. R. Assoc. Franç., Congrès d'Oran, p. 680. Also Mon. Anf. An. Ital. p. 61 (1883).

2 Zoologist, 1884, pp. 220, 265 ; Proc. Zool. Soc. 1884, p. 573, pl. lv., and 1885 , p. 666 , pl. xl.

Bull. Soc. Mosc. 1889, p. 242. 
$\boldsymbol{R}$. tigrina, Eichw., $\boldsymbol{R}$. dentex, Kryn., ?R. maritima, Risso, $R$. hispanica, Mich., vars. latastii, bedriaga, Cam., R. fortis, Boul., var. perezi, Seoane.

This is the largest and most widely distributed form, inhabiting the whole of Europe with the exception of the North-western and Central parts and Italy, Western Asia as far east as North Baluchistan, A fghanistan, and Eastern Turkestan, and North Africa. As being on the whole the least specialized form, $i$. $e$. departing less from the normal pattern of the genus to which it belongs, it deserves to rank first in the list, although the denomination of forma typica pertains to the next form, as having been first described under the name of $\boldsymbol{R}$. esculenta.

2. Forma tYPICA.

$=R$. esculenta, L., R. viridis aquatica, Rös., var. silvatica, Koch (type examined).

Northern and Central Europe, Italy, Russia.

3. Var. LESSON Æ.

$=$ var. lessonce, part., Cam.

The habitat of this Frog, which in its characters is intermediate between the preceding and the next, is still very incompletely ascertained, specimens being known from England (Cambridgeshire and Norfolk), the Rhine, the province Saxony, Piedmont and probably other parts of Italy, and Malta. The British specimens are most likely introduced from Italy. The opinion recently expressed by Bedriaga, that Bell's $R$. scotica may belong to this form, is due to his having misunderstood that author. The figure given in the first edition of the 'British Reptiles,' and which has been reproduced in the second edition and copied by Ecker (Anat. des Frosches), is " taken from a foreign specimen," and represents $\boldsymbol{R}$. esculenta typica. Bell's $\boldsymbol{R}$. scotica is a synonym of $R$. temporaria.

\section{Var. Nigromaculata.}

$=R$. marmorata, Hallow.; R. nigromaculata, Hallow.; Hoplobatrachus reinhardti, Peters; Tomopterna porosa, Cope ; var. japonica, Boul.

The name japonica should be reserved for a species of the temporaria-group ; and $R$. esculenta, var. marmorata, Massal., is of earlier date than $\boldsymbol{R}$. marmorata, Hallow. I therefore adopt the name nigromaculata, Hallow., which stands next on the list of synonyms. This Eastern form ranges from Corea and Japan to Southern China and Siam; the exact western limits of its habitat have still to be ascertained, and it would be particularly desirable to know whether it anywhere comes into contact with or overlaps the area of the ridibunda form.

The principal characters which have proved of service in diagnosing these forms are the following:-

1. The development of the inner metatarsal tubercle, whether 
large or small, blunt or compressed. The length indicated in the measurements below is the basal, $i$. e. taken along the attachment of the tubercle to the foot; the length of the first toe, given for comparison, is taken from the tubercle; and the length of the tubercle is also compared to the length of the crus or tibia measured in the flesh.

2. The comparative length of the tibia to the thigh; this is shown by pressing the two close together and maintaining the tibia at right angles to the axis of the body ; the tibial extremity is then found to overlap, to meet or to fail to meet its fellow placed in the same position. Only in form 1 do they overlap ${ }^{1}$, and this character alone differentiates it from the three others.

3 . The presence or absence of short glandular folds along the back, in audition to the glandular dorso-lateral fold. The presence of these folds differentiates form 4 from the three others.

4. The presence or absence of bright yellow pigment on the lumbar and post-femoral regions. This pigment is constantly absent in form 1, and very seldom in form 2. The character unfortunately cannot be made use of with spirit-specimens.

By means of these characters we are able to draw up the following key, which is imperfect only in so far that forms 2 and 3 are not distinguished from each other in an absolute manner; this difficulty, however, cannot be overcome, as the two forms do run completely into one another, and future investigations may even render their separation unadvisable.

\begin{tabular}{|c|c|c|c|c|c|c|c|}
\hline & Heels overlapping. & $\begin{array}{l}\text { 1. ridibunda. } \\
\text { 2. typica. }\end{array}$ & Met. tub & $2 \frac{1}{2}-4$ & 营 & $\begin{array}{r}9 \frac{1}{2}-14 \\
7-10\end{array}$ & ). \\
\hline folds. & $\begin{array}{l}\text { Heels not over- } \\
\text { lapping }\end{array}$ & 3. lessone. & ", & $1 \frac{1}{2}-2$ & : & $5-8$ & \\
\hline Dorsal fol & & 4. nigromac & $"$ & $1-1 \frac{2}{3}$ & . & $5-8$ & $\varepsilon$ \\
\hline
\end{tabular}

Other characters have been added to complete the definitions.

In the following tables a complete list of the specimens in the British Museum is given, together with measurements taken from individuals from various localities. In these measurements the figures in column 1 give the length, in millimetres, from snout to vent; in column 2, the length of the tibia; in column 3 , the length of the foot measured from the outer metatarsal tubercle to the end of the fourth toe ; in column 4, the length of the inner toe; and in column 5 , the length of the inner metatarsal tubercle.

The specimens enumerated are but a portion of the material studied, a picked series, in which consequently abnormal specimens, $i$. $e$. such as fit least well in the technical definitions, are in greater proportion than in collections made without discrimination. The number of specimens in the Museum is also greater than appears from the figures, as I have abstained from counting in any case

1 As in the various species of the temporaria-group; all of which, however long or short the hind limbs, possess this character. 
more than 10 specimens in each bottle; and the skeletons are not enumerated.

\section{Var. RIDIBUNDA.}

Inner metatarsal tubercle small, blunt, feebly prominent, its length $2 \frac{1}{2}$ to 4 times in the length of the inner toe measured from the tubercle, and $9 \frac{1}{2}$ to 14 times in the length of the tibia (in the flesh); when the limbs are folded at right angles to the body, the extremities of the tibiæ overlap ; tibia as long as or slightly shorter than the foot measured from the outer metatarsal tubercle. Skin smooth or more or less warty ; glandular lateral fold more or less prominent, frequently as broad as the upper eyelid. Olive, dull green, or bronzy brown above, rarely bright green, spotted or speckled with dark olive or blackish; the spots never forming longitudinal bands; no bright yellow pigment on the back of the thighs; vocal sacs grey.

Measurements.

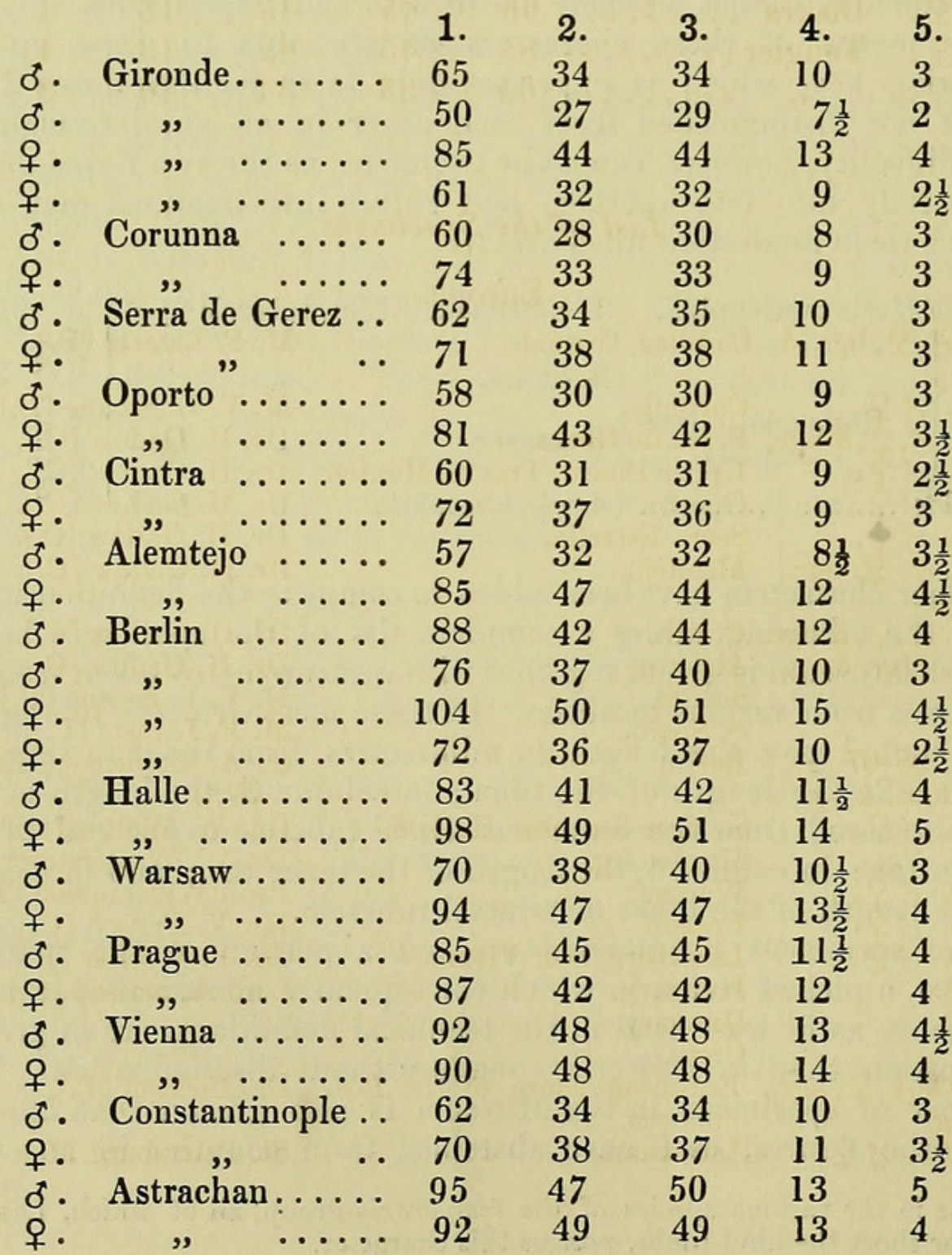


Measurements (continued).

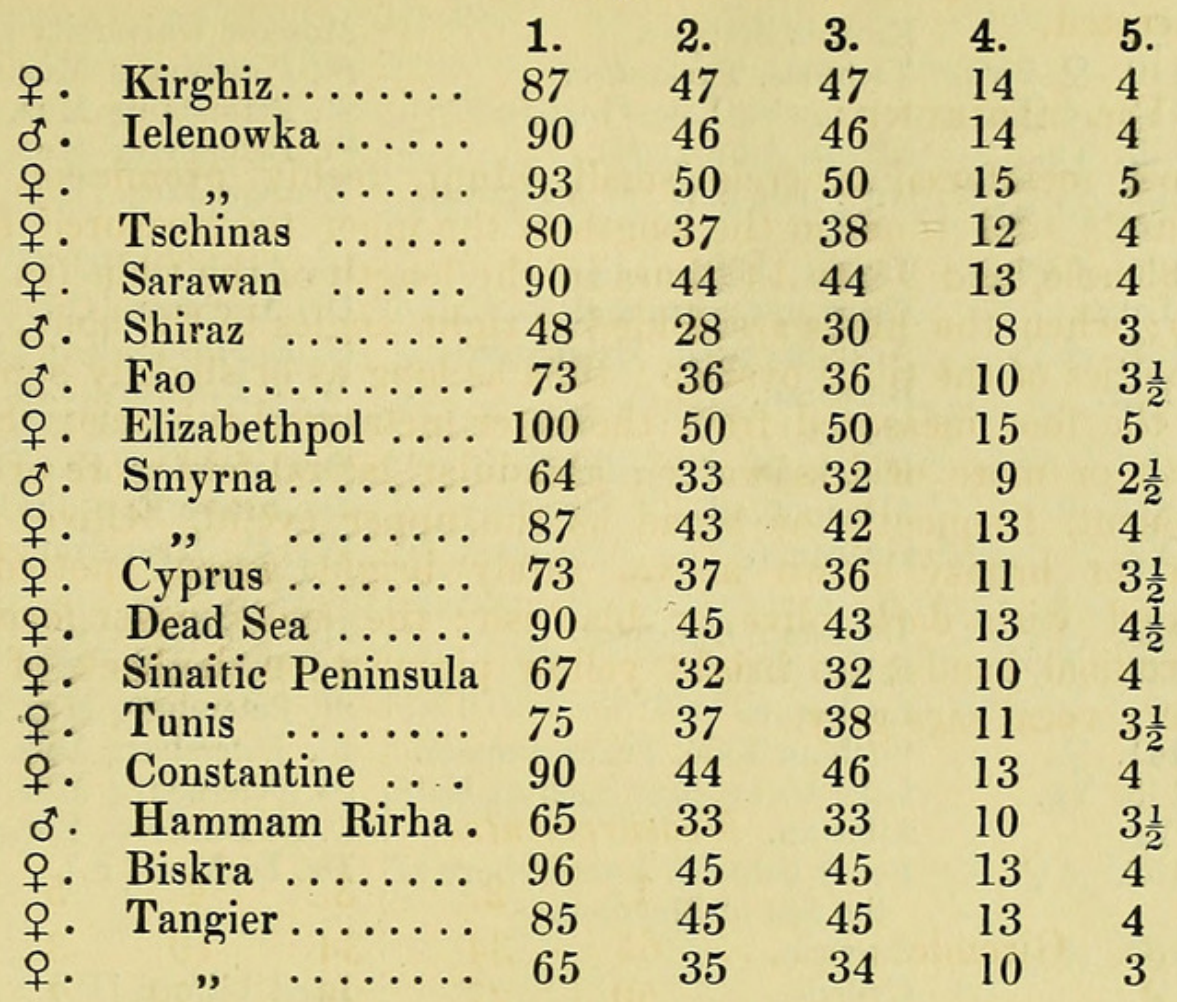

List of the Specimens.

\section{Europe.}

1-10. $\delta^{\circ}$,, hgr., \& Cadillac, Gironde. yg.

11-14. 우오. Corunna.

15-19. $0^{x}, 0$, \& hgr. Serra de Gerez.

20-21. 0 오.

22-25. 0 우.

26-28. o 오.

29-37. $\delta$, 오, hgr.,

\& yg.

38-41. $\sigma^{\circ}$, o , \& hgr. Cintra.

42-45. Hgr. \& yg. Algarve.

46. $0^{\pi}$.

47. 0 .

Seville.

S. Spain.

48-57, 58-67. ' 0 , Berlin.

ㅇ, hgr., \& yg.

68-73. 우오.

74-76. $\mathrm{Yg}$.

77-80. 호오.

81-86. 0 .

87-90. 어오.

91. 오.

92. 오.

93. 오.

94-103. o , 오, hgr.,

Salziger See, near Halle/S.

Magdeburg.

Warsaw.

Prague.

Laaerberg, near Vienna.

Hungary.

Hungary.

Crete.

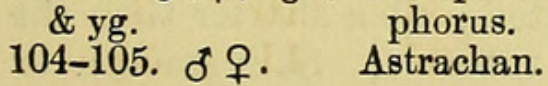

M. F. Lataste [P.].

M. V. I. Seoane [P.]

Dr. H. Gadow [C.].

Dr. H. Gadow [C.].

Dr. H. Gadow [C.].

Dr. H. Gadow [C.].

Dr. H. Gadow [C.].

Dr. H. Gadow [C.].

Dr. H. Gadow [C.].

M. V. L. Seoane [P.].

M. F. Lataste [P.].

G. A. Boulenger, Esq. [P.].

Dr. W. Wolterstorff [P.]

Dr. W. Wolterstorff [P.]

Prof. Wrzeniowski [P.].

Hr. V. Fritsch [C.].

Dr. F. Werner [P.]

Lord A. Russell [P.]

Dr. Dickson [P.].

St. Petersburg Mus. [P.]. 
Asia.

106. 오.

107-110.

$111-114 .+8$ \&g.

115-116. Yg.

117-123. $0^{7}$, 오, \& yg.

124-125. ơ \& hgr.

126. Larva.

127-128. ơ 오.

129. $\mathrm{Hgr}$.

130. 오.

131. 0 .

132. 오.

133. $\stackrel{\mathrm{Y} g}{\mathrm{~g}}$.

134-135. 후오.

136-138. 우오.

139. 오.

140-141. 오.

142-145. Yg.

146. $\mathrm{Yg}$.

147-152. 우오.

153-154. 우우.

155. 오.

156. 오.

157-158. రా.

159. 오.

160-161. 우 오.

162. ठ".

163. 오.

164-165. 오 \& hgr. Sinaitic Peninsula.

Kirghiz Steppes.

Nukus, Amu Daria.

Bussorah.

Shiraz.

Mesopotamia.

Guezama.

Elizabethpol.

Lenkoran. Albistan.

Smyrna.

Cyprus.

Sea of Galilee.

Plains of Phœnicia.

Merom.

Dead Sea.

Jericho.

Damascus.
Moscow University [E.].

Tschinas, Turkestan.

Ielenowka, Lake Goktsha.

Guermab, S.W. of Ashkabad.

Turbat, Afghanistan.

Between Quetta and Nushki.

Near Sarawan, Baluchistan.

Fao, head of Persian Gulf.

Dagestan, Caucasus.

Suchum Kalé, Transcaucasia.

Lake Abran, near Suchum Kalé.

Fener-bahtchi, Asiatic shore of the Sea of Marmora.

.

St. Petersburg Mus. [E.].

St. Petersburg Mus. [E.].

Warsaw Mus. [E.].

Dr. Aitchison [C.].

Dr. Aitchison [O.].

G. E. Mason, Esq. [P.].

W.T.Blanford, Esq. [C.].

W. T. Blanford, Esq. [O.].

D. Cumming, Esq. [P.].

Euphrates Expedition.

W. C. Trevelyan, Esq. [P.].

Moscow University [E.]

St. Petersburg Mus. [E.].

St. Petersburg Mus. [E.].

St. Petersburg Mus. [E.].

St. Petersburg Mus. [E.].

C. G. Danford, Esq. [P.].

Dr. Dickson [P.].

Lord Lilford [P.]

Canon Tristram [C.].

Canon Tristram [C.].

Canon Tristram [C.].

Canon Tristram [C.].

Dr. J. Anderson [P.].

Dr. J. Anderson [P.].

H. C. Hart, Esq. [P.].

Africa.

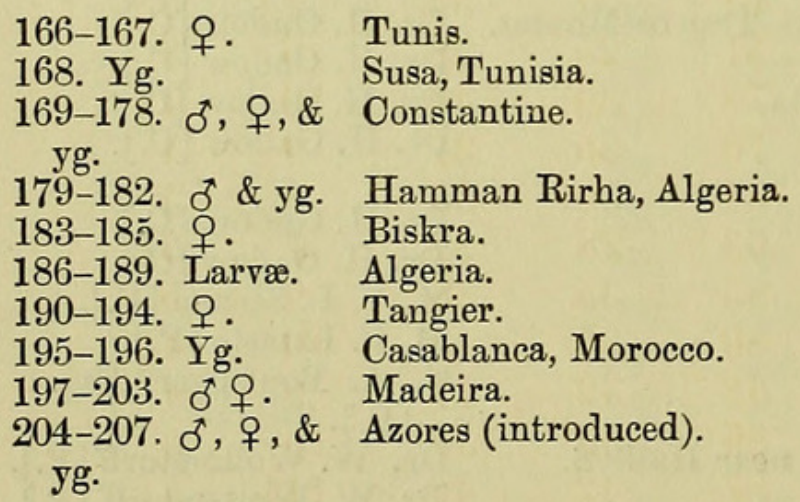

Mr. Fraser [C.].

Mr. Fraser [C.].

P. L. Sclater, Esq. [P.].

Dr. J. Anderson [P.]

Dr. J. Anderson [P.].

M. Héron Royer [E.].

M. H. Vaucher [C.].

Senckenberg Mus. [E.].

Prof. Lütken [P.].

F. D. Godman, Esq. [P.].

\section{Forma typica.}

Inner metatarsal tubercle strong, compressed, prominent, its length 2 to 3 times in the length of the inner toe measured from the tubercle, and 7 to 10 times in the length of the tibia; when the limbs are folded at right angles to the body, the extremities of the tibiæ meet or remain narrowly separated; tibia shorter than the foot measured from the outer metatarsal tubercle. Skin smooth or with small warts; glandular lateral fold very prominent, as broad as or narrower than the upper eyelid. Bright green, brown, or blue 
above, uniform or spotted with black; hinder side of thighs handsomely marbled with black, and usually with more or less of bright yellow pigment; vocal sacs white or feebly pigmented.

The range of variation of the somewhat complex assemblage which I have endeavoured to define as the typical form is very great indeed and forms a gradated series leading from the form ridibunda to the form lessonce.

I must confess that the line drawn between the latter and the typical form appears to me arbitrary, and that my arrangement is open to this criticism, that there is altogether a greater amount of difference between the two extremes of the series than there is between the extreme in the lessonce direction and the form lessonce itself. The true typical $R$. esculenta, as figured by Rösel, is pretty well in the middle of the series: the extreme specimens with small inner metatarsal tubercle are from France, Corsica, and Italy ; whilst the opposite extreme obtains in the specimens from Basle and Vienna.

\section{Measurements.}

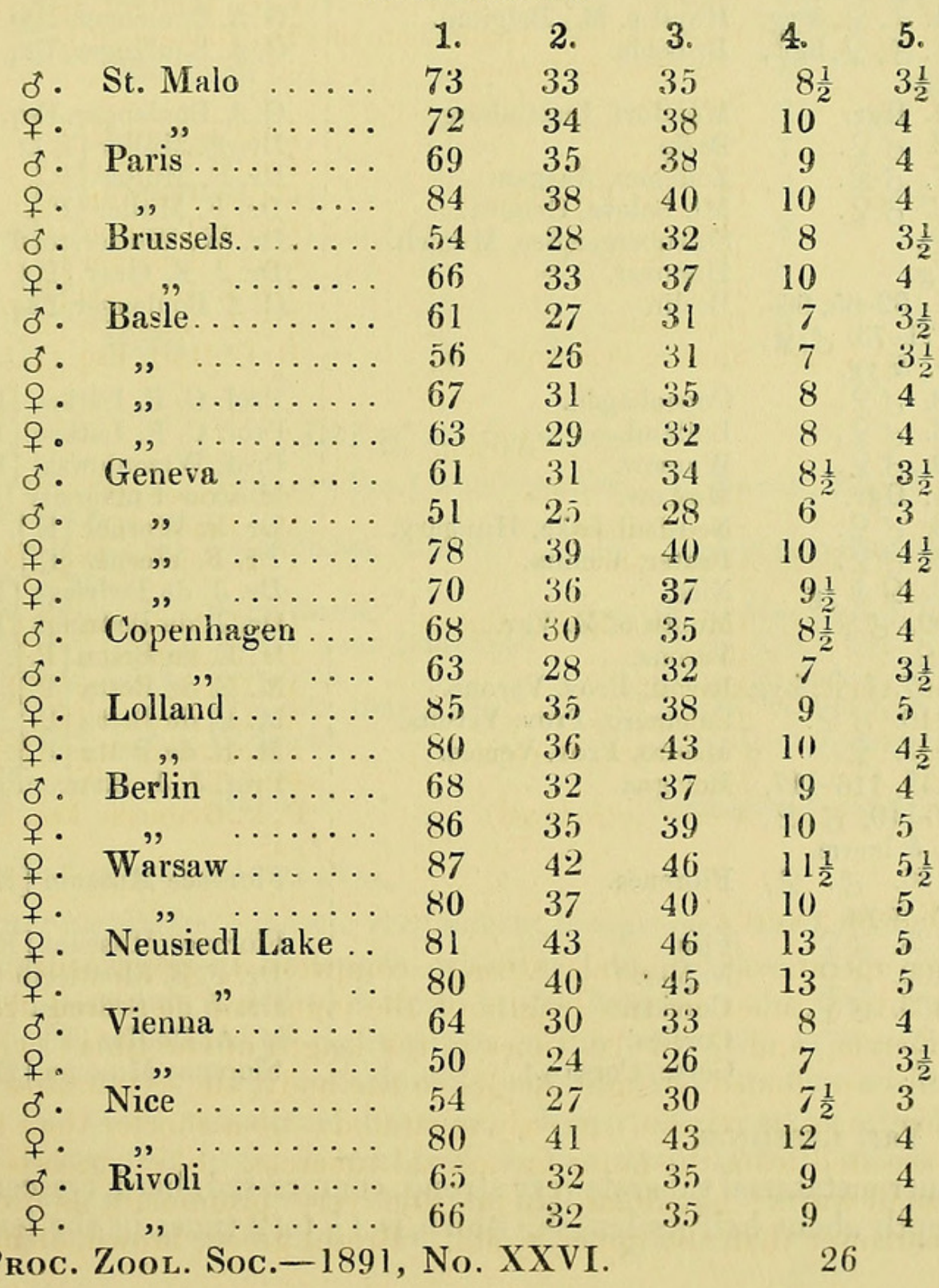


Measurements (continued).

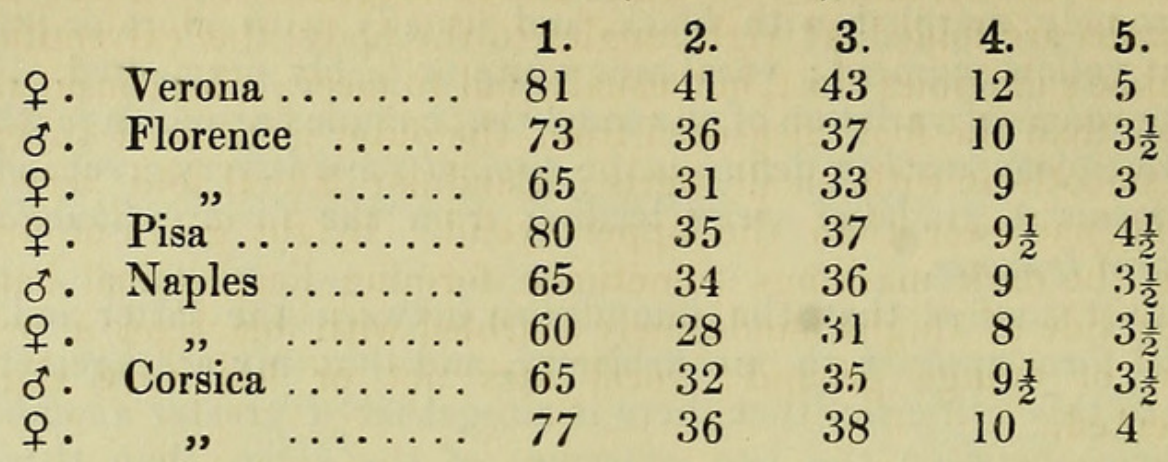

\section{List of the Specimens.}

1, 2. 8 .

3-10. on, ㅇ, hgr., Near St. Malo. $\&$ larva.

11-12. 0 오.

13-14. 0 오.

15-24. o, o, \& yg.

25-31. o, o , hgr., $\& \mathrm{yg}$.

32-34. Hgr.

$35-42.00$.

43-47. 0 우.

48-52. ơ

53. 오.

54. $\mathrm{Y} g$.

$55-61,62-65,66-$ 70,71-73. 0 ,, , hgr., \& yg.

74-78. $0^{7}$ 오.

79-83. 오.

84-89. 웅.

90-91. Hgr.

92-93. $\delta$ 우.

94-96. 오.

97-98. ㅇ \& yg.

99-100. 0 중.

101. 오.

102-107. $0^{\star}$, , ㅇ, \& yg. Rivoli, Prov. Verona.

108-110.

111-113. ㅇ. .

114-115, 116-117, Bologna.

Paris.

Argenton, Indre.

Heyst s. M., Belgium.

Brussels.

Mondorf, Luxemburg.

Basle.

Zofingen, Aargau.

Mt. Saleve, Geneva.

Starnberger See, Munich.

Hanover.

Berlin.

Copenhagen.

Lolland.

Warsaw.

Moscow.

Neusiedl Lake, Hungary.

Prater, Vienna.

Nice.

Mouth of R. Var.

Verona.

Mestre, Prov. Venice.

118-119. 하 , 오

yg., \& larvæ.

120-126. ot, ㅇ, Florence. hgr., \& yg.

127-128. 응 Pisa.

129-132. $0^{x}$. Naples.

133-135. ơ 오. Corsica.

136. 으 Corsica.

137. ठ. Corte, Corsica.
W. Amhurst Amherst, Esq. [P.].

G. A. Boulenger, Esq. [P.].

G. A. Boulenger, Esq. [P.] M. R. Parâtre [E.].

G. A. Boulenger, Esq. [P.]

G. A. Boulenger, Esq. [P.].

G. A. Boulenger, Esq. [P.] Dr. F. Müller [P.].

Dr. F. Müller [P.].

Dr. F. Müller [P.].

Dr. W. Wolterstorff [P.]

Dr. J. E. Gray [P.].

G. A. Boulenger, Esq. [P.].

Prof. C. F. Lütken [P.].

Prof. C. F. Lütken [P.].

Prof. Wrzeniowski [P.].

Moscow University [E.]

Dr. F. Werner [E.].

Dr. F. Werner [E.].

Dr. J. de Bedriaga [P.].

Dr. J. de Bedriaga [P.].

M. E. de Betta [P.].

M. E. de Betta [P.].

M. E. de Betta [P.].

M. E. de Betta [P.].

Prof. J. J. Bianconi [P.].

Florence Museum [E.].

Florence Museum [E.]

Dr. F. S. Monticelli [P.]. Dr. J. de Bedriaga [P.].

M. A. Dollfus $[\mathrm{P}]$.

Florence Museum [E.]

3. Var. LESSONA.

Inner metatarsal tubercle very strong, compressed, hard, crescentic, its depth about half its length, which is $1 \frac{1}{2}$ to 2 times in the length 
of the inner toe, and 5 to 8 times in the length of the tibia; when the limbs are folded at right angles to the body, the extremities of the tibiæ sometimes meet, but usually fail to meet ; tibia considerably shorter than the foot measured from the outer metatarsal tubercle. Skin smooth or with small warts; glandular lateral fold very prominent, narrower than the upper eyelid. Bright green or brown above, the dark markings sometimes forming longitudinal bands; hinder side of thighs handsomely marbled with black on a bright yellow or orange ground; vocal sacs not or but very slightly pigmented.

Measurements.

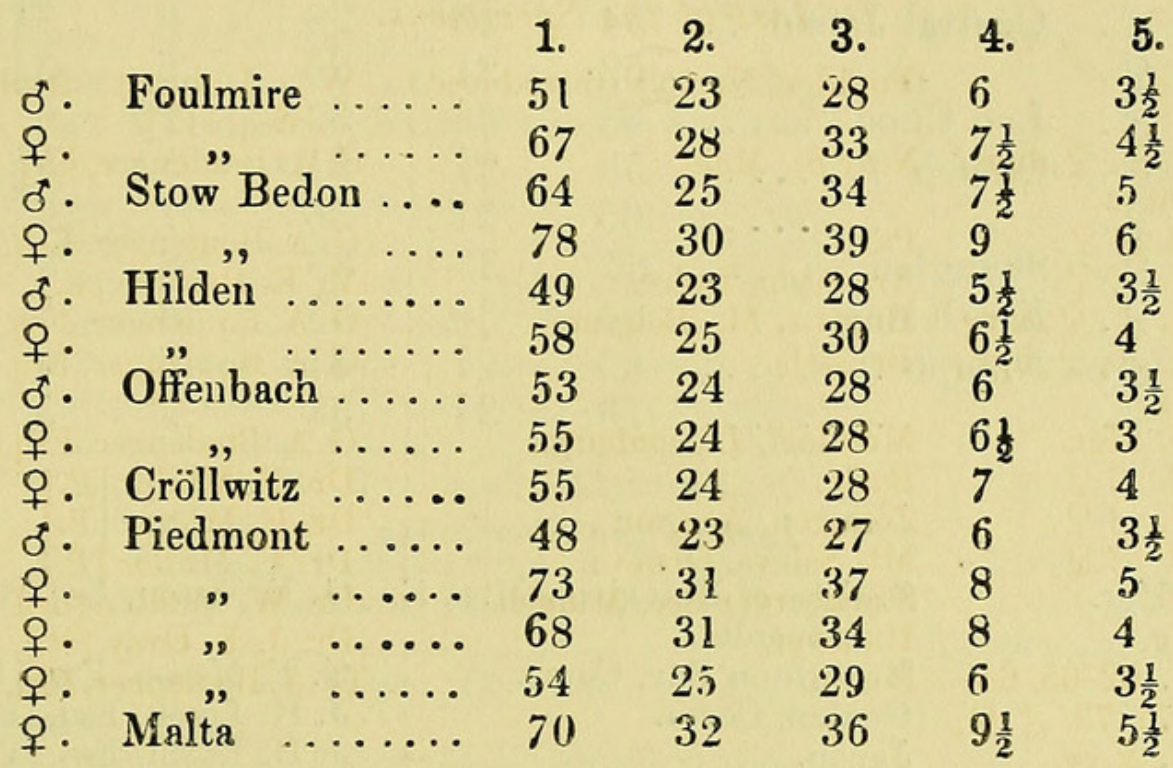

\section{List of the Specimens.}

1-3, 4-6. o, 우, Foulmire Fen, Cambridgeshire. W. Yarrell, Esq. [P.]. hgr., \& yg.

7-12, 13. $\delta^{7}$, 오 , Stow Bedon, Norfolk. hgr., \& yg.

14-18. $\mathrm{Yg}$.

19-22. 0 ㅇ․

Stow Bedon.

23-26. o, 9 , \& hgr. Offenbach.

27. ㅇ. Cröllwitz, near Halle.

28-37. o, + , hgr., Piedmont.

\& yg.

38. + .

Malta.

Lord Walsingham [P.].

G. E. Mason, Esq. [P.].

W. E. Kirby, Esq. [P.].

Dr. J. de Bedriaga [P.].

Dr. W. Wolterstorff [P.].

Prof. L. Camerano [P.].

Zoological Society [P.].

\section{Var. NigROMACUlata.}

Inner metatarsal tubercle very strong, compressed, hard, crescentic, its depth about half its length, which is 1 to $1 \frac{2}{3}$ times in the length of the inner toe, and 5 to 8 times in the length of the tibia; when the limbs are folded at right angles to the body, the extremities of the tibiæ meet; tibia considerably shorter than the foot measured from the outer metatarsal tubercle. Interrupted narrow glandular folds along the back, in addition to the dorso-lateral, which are well-marked and narrower than the upper eyelid. Green or brown above, the black markings often forming longitudinal bands; hinder 
side of thighs handsomely marbled with black on a yellow ground; sometimes a light line running along the inner upper side of the tibia; vocal sacs more or less pigmented.

\section{Measurements.}

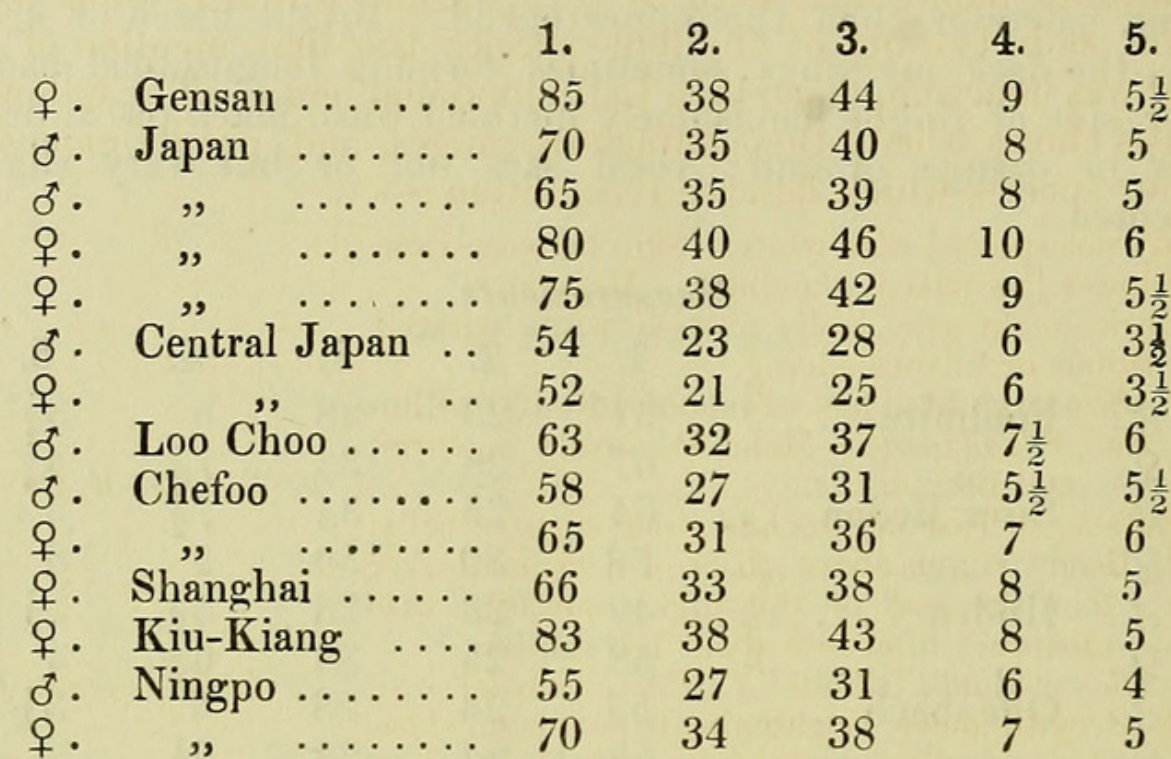

List of the Specimens.

1-2. Hgr.

3. 오.

4. ㅇ..

5. ㅇ․

$6-8,9-10$.

11-17. 0,,$+\& \mathrm{yg}$.

18. 오.

19. $0^{\circ}$.

20. $\delta^{\circ}$.

21-28. ठ, , क, hgr.,

$\& \mathrm{yg}$.

29-34, 35-37, 38-

39. 0 , 오, \& hgr.

$40-41$. ㅇ \& hgr.

42 , 오.

43-44, 45. ơ, \&, Ningpo. \& yg.

46-48. Yg. Bangkok, Siam. Mongolia.

Gensan, Corea.

Japan.

Japan.

Central Japan.

Yokohama.

Chefoo.

Shanghai.

Chusan.
S. slope of Khingham Mts., E. G. E. Mason, Esq. [P.].

Broughton Bay, Corea. $\quad$ G. E. Mason, Esq. [P.].

Hakone Lake, Japan.

Great Loo Choo Island.

Mountains north of Kiu-Kiang. A. E. Pratt, Esq. [C.].
J. H. Leech, Esq. [P.].

J. H. Leech, Esq. [P.].

Leyden Museum.

Dr. J. Anderson [P.].

Dr. J. Anderson [P.].

Dr. J. Anderson [P.].

G. E. Mason, Esq. [P.].

R. Swinhne, Esq. [C.].

R. Swinhoe, Esq. [C.].

R. Swinhoe, Esq. [C.].

G. E. Mason, Esq. [P.].

2. Notes on some Ungulate Mammals. By Oldfield Thomas, F.Z.S.

[Received May 28, 1891.]

The following notes have been put together during the preparation of a list of the specimens of Ungulata in the British Museum Collection, and it is hoped they may help to clear up some of the difficulties in the systematic arrangement of these animals. 


\section{$2 \mathrm{BHL}$ Biodiversity Heritage Library}

Boulenger, George-Albert. 1891. "A Contribution to the Knowledge of the Races of Rana esculent a and their Geographical Distribution." Proceedings of the Zoological Society of London 1891, 374-384.

https://doi.org/10.1111/j.1096-3642.1891.tb01762.x.

View This Item Online: $\underline{\text { https://www.biodiversitylibrary.org/item/99645 }}$

DOI: https://doi.org/10.1111/j.1096-3642.1891.tb01762.x

Permalink: https://www.biodiversitylibrary.org/partpdf/72881

\section{Holding Institution}

Smithsonian Libraries

\section{Sponsored by}

Biodiversity Heritage Library

\section{Copyright \& Reuse}

Copyright Status: Public domain. The BHL considers that this work is no longer under copyright protection.

This document was created from content at the Biodiversity Heritage Library, the world's largest open access digital library for biodiversity literature and archives. Visit BHL at https://www.biodiversitylibrary.org. 